\title{
Myricetin induces apoptosis and autophagy by inhibiting PI3K/Akt/mTOR signalling in human colon cancer cells
}

\author{
Ming-liang Zhu', Pei-min Zhang ${ }^{2}$, Min Jiang ${ }^{1}$, Shu-wen $\mathrm{Yu}^{1,2^{*}}$ and Lu Wang ${ }^{1,2^{*}}$ (D)
}

\begin{abstract}
Background: The compound 3,3', $4^{\prime}, 5,5^{\prime}, 7$-hexahydroxyflavone (myricetin) is a natural flavonoid with antitumour activity. Most of the studies on myricetin have focused on the induction of tumour cell apoptosis, and little is known about the regulatory effects of myricetin on autophagy in colorectal cancer.

Methods: Here, we studied the effects of myricetin on colon cancer cell proliferation, apoptosis and autophagy. We detected colon cancer cell apoptosis induced by myricetin via flow cytometry and Hoechst 33258 staining.

Transmission electron microscopy was performed to observe the morphological changes associated with autophagy. The expression levels of apoptosis-, autophagy- and PI3K/Akt/mTOR signalling-related proteins were measured by Western blot analysis.

Results: This study confirmed that myricetin inhibits the proliferation of 4 kinds of colon cancer cell lines. Myricetin induced cell apoptosis and autophagy by inhibiting PI3K/Akt/mTOR signalling pathway. In addition, the inhibition of autophagy with 3-methyladenine (3-MA) promoted the apoptosis of myricetin-treated colon cancer cells.

Conclusions: Considering that myricetin induces apoptosis and autophagy in colon cancer cells, myricetin may become a viable candidate for chemotherapy; it could be used to exert tumour inhibitory effects alone or as adjuvant chemotherapy to inhibit autophagy. These studies may provide further evidence for the potential use of myricetin in the treatment of colon cancer.
\end{abstract}

Keywords: Myricetin, Autophagy, Apoptosis, Colon cancer, 3-MA

\section{Background}

Colorectal cancer is the third most common and second deadliest cancer worldwide, with an estimated 1.8 million new cases and 862,000 attributed deaths in 2018 [1]. Treatment of colorectal cancer is multifaceted and may include a combination of surgery, radiation therapy, chemotherapy, and targeted therapies such as checkpoint inhibitors and anti-angiogenesis therapies [2]. Despite improved treatment options, drug resistance exists

\footnotetext{
* Correspondence: yaoxuebu2012@163.com; lulucc@163.com

'School of Pharmaceutical Sciences, Cheeloo College of Medicine, Shandong University, Jinan 250012, China

Full list of author information is available at the end of the article
}

for some patients receiving traditional chemotherapeutics [3]. For this reason, new chemotherapy drugs are needed in the clinic.

Myricetin (3,3',4',5,5',7-hexahydroxyflavone) is a natural flavonoid pigment commonly found in fruits, herbs, and nuts $[4,5]$. Myricetin differs from other flavonols in the presence of the $3^{\prime}, 4^{\prime}, 5^{\prime}$-trihydroxy. Myricetin has been found to have anticancer properties in a variety of malignancies, including prostate [6], breast [7], gastric [8], and lung cancers [9] (Fig. 1). However, there are few studies on the role of myricetin in colorectal cancer. Kim et al. and Nirmala et al. showed that myricetin could inhibit the growth of colorectal cancer in vitro

C C The Author(s). 2020 Open Access This article is licensed under a Creative Commons Attribution 4.0 International License, which permits use, sharing, adaptation, distribution and reproduction in any medium or format, as long as you give appropriate credit to the original author(s) and the source, provide a link to the Creative Commons licence, and indicate if changes were made. The images or other third party material in this article are included in the article's Creative Commons licence, unless indicated otherwise in a credit line to the material. If material is not included in the article's Creative Commons licence and your intended use is not permitted by statutory regulation or exceeds the permitted use, you will need to obtain permission directly from the copyright holder. To view a copy of this licence, visit http://creativecommons.org/licenses/by/4.0/ The Creative Commons Public Domain Dedication waiver (http://creativecommons.org/publicdomain/zero/1.0/) applies to the data made available in this article, unless otherwise stated in a credit line to the data. 


Sources:
Teas
Werries
$\begin{array}{ll}\text { Fruits } \\ \text { Vegetables }\end{array}$
$\ldots$

and in vivo $[10,11]$. In 2018 , Lee et al. suggested that myricetin selectively induces the apoptosis of HCT-15 colon cancer cells by increasing the expression of nucleoside diphosphate kinase and other caspase-regulated apoptosis proteins [12].

Apoptosis and autophagic cell death are two types of programmed cell death. An apparent conundrum is that autophagy acts in cytoprotection and in cell death. While these processes are different, there is a complex connection between apoptosis and autophagy [13]. Currently, there is no research on whether myricetin can induce autophagy in colorectal cancer cells. Therefore, we aimed to evaluate the role and mechanism of action of myricetin in the treatment of colorectal cancer. The findings demonstrated that myricetin could induce colorectal cancer cell apoptosis and autophagy and that the PI3K/AKT/mTOR signalling pathway might be involved in myricetininduced cell proliferation, apoptosis and autophagy. In addition, inhibition of autophagy with 3Methyladenine (3-MA) promoted myricetin-induced apoptosis of colorectal cancer cells.

\section{Methods \\ Reagents}

Myricetin, Hoechst Staining Kit (G3680) and resazurin were purchased from Solarbio Life Sciences (Beijing, China). 3-MA (S2767) was purchased from Selleck Chemicals (Houston, TX, USA). The primary antibodies included Bax (5023S), Bcl-2 (15071S), Microtubuleassociated protein1 light chain 3 (LC-3) I/II (12741S), Beclin-1 (3495S), Phosphatidyl inositide 3-kinase (PI3K) (13666S), phospho-PI3K (4228S), phospho-Akt (4060S), Akt (2920S), Mammalian target of rapamycin (mTOR) (2983S), phospho-mTOR (5536S) were purchased from Cell Signaling (MA, USA). $\beta$-actin (60008-1) was purchased from ProteinTech Group (Wuhan, China). Horseradish peroxidase-conjugated secondary antibodies (ZB-2301, ZB-2305) were purchased from ZSGB-Bio (Beijing, China).

\section{Cell culture and treatment}

Four human colorectal cancer cell lines, HT-29, HCT116, SW480 and SW620, were obtained from American Type Culture Collection (ATCC, Manassas, VA, USA). The cells were cultured in RPMI-1640 medium with $10 \%$ foetal bovine serum (Solarbio Science \& Technology, Beijing, China) at $37^{\circ} \mathrm{C}$ in a $5 \% \mathrm{CO}_{2}$ atmosphere.

\section{Cell viability assay}

Cell viability was measured with the resazurin cell viability assay. The cells were seeded at a density of $2 \times 10^{4}$ cells/well in 96-well culture plates. After $4 \mathrm{~h}$, different concentrations of myricetin $(0,12.5,25,50$, 100,200 , and $400 \mu \mathrm{mol} / \mathrm{L}$ ) were added and incubated for $24 \mathrm{~h}, 48 \mathrm{~h}$, and $72 \mathrm{~h}$. Cells incubated with culture medium with an equivalent amount of vehicle dimethyl sulfoxide (DMSO) served as controls. Next, $20 \mu \mathrm{L}$ of deep blue-coloured resazurin solution (freshly prepared) was added to each group and incubated for $4 \mathrm{~h}$. The absorbance was measured at excitation/emission wavelengths of 560/590 nm with a microplate reader to determine the cell survival rate [14].

\section{Hoechst 33258 staining}

Colorectal cells were seeded at a density of $2 \times 10^{5}$ cells $/ \mathrm{mL}$ in 6 -well plates. After fixation with $3.7 \%$ paraformaldehyde for $30 \mathrm{~min}$ at $37^{\circ} \mathrm{C}$, the cells were washed with phosphate-buffered saline (PBS) and treated with $10 \mathrm{mg} / \mathrm{L}$ Hoechst 33258 for $15 \mathrm{~min}$. A fluorescence microscope was used to observe the colorectal cells. When cells are apoptotic, the chromatin will condense. Therefore, after Hoechst 33258 staining, under a fluorescence microscope, condensed apoptotic nuclei should have a strong fluorescence intensity increase and be smaller than normal nuclei. In addition, there were vesicles in the cell membrane and apoptotic bodies in apoptotic cells [15]. 


\section{Transmission electron microscopy}

Autophagosome formation was detected using conventional electron microscopy using a previously established protocol [16]. First, the cells were fixed with $2.5 \%$ glutaraldehyde and $2.5 \%$ formaldehyde for $2 \mathrm{~h}$ before being incubated with $1 \% \mathrm{OsO}_{4}$ for $1 \mathrm{~h}$. Next, the cells were soaked in $2 \%$ uranyl acetate for $1 \mathrm{~h}$ and processed sequentially using acetone/Spur's resin $(1,1)$, ethanol, and $100 \%$ Spur's resin. Transmission electron microscopy was used to visualize the ultrathin sections of cells.

\section{Western blot analysis}

The colorectal cancer cells were inoculated into 6-well plates at a density of $4 \times 10^{5}$ cells $/ \mathrm{mL}$ and cultured at $37^{\circ} \mathrm{C}$ overnight. Different concentrations of myricetin $(25,50$, and $100 \mu \mathrm{mol} / \mathrm{L})$ were added the next day, and a blank control group $(0 \mu \mathrm{mol} / \mathrm{L}$ myricetin $)$ was set up. The cells were collected after $48 \mathrm{~h}$ of incubation. Total cellular protein was extracted with radioimmunoprecipitation assay (RIPA) buffer. The proteins were separated on $10 \%$ sodium dodecyl sulfate (SDS)-polyacrylamide gels. After the bands were transferred to a polyvinylidene fluoride (PVDF) membrane, the membrane was blocked with $5 \%$ milk. Next, the membrane was incubated with the primary antibodies at $4{ }^{\circ} \mathrm{C}$ overnight. After washing three times with PBS for $10 \mathrm{~min}$, the membrane was incubated with the secondary antibody for $45 \mathrm{~min}$ at room temperature [17].

\section{Flow cytometry assays}

The cells were treated and collected as described above, and flow cytometry was performed using the Annexin V/Propidium iodide (PI) Apoptosis kit (Sigma, America). The cells were washed three times with PBS and resuspended in $1 \times$ binding buffer. Next, the cells were incubated in the dark with $5 \mu \mathrm{L}$ of Annexin V-FITC and $10 \mu \mathrm{L}$ of propidium iodide for 5 min each [18]. The samples were run on a FACSCalibur flow cytometer (BD Bioscience, San Jose, CA, USA), and the data were processed using FlowJo 10 (FlowJo, LLC, Ashland, OR, USA). Both early and late apoptotic cells were considered.

\section{Statistical analysis}

Statistical analysis was performed by Student's t-test for pair samples using SPSS/Win 13.0 software. The results are expressed as the mean $\pm \mathrm{SD}$, and significant outcomes are indicated as follows: ${ }^{*} p<0.05,{ }^{* * *} p<0.01$, and $* *: p<0.001$.

\section{Results}

\section{Myricetin inhibited the viability of human colorectal} cancer cells

We investigated the effects of myricetin on four different human colorectal cancer cell lines (HT-29, HCT116,
SW480, SW620) by means of a resazurin cell viability assay. Colorectal cells were treated with 6 concentrations of myricetin $(12.5,25,50,100,200$ and $400 \mu \mathrm{mol} / \mathrm{L})$ for $48 \mathrm{~h}$. The results showed that HCT116 and SW620 cells were more sensitive to myricetin than the other two cell lines, and their $\mathrm{IC}_{50}$ values were 83.45 and $233.4 \mu \mathrm{mol} / \mathrm{L}$, respectively (Table 1 ). Therefore, these two cell lines were selected for subsequent experiments. Myricetin inhibited the proliferation of HCT116 and SW620 cells in a dose-dependent manner. Since there was no significant difference in cell survival between the $48 \mathrm{~h}$ and $72 \mathrm{~h}$ treatments with myricetin, $48 \mathrm{~h}$ was selected for the subsequent experiments (Fig. 2).

\section{Myricetin induced apoptosis of HCT116 and SW620 cells}

Here, we verified the effects of myricetin on the apoptosis of colon cancer cells via Hoechst 33258 staining. Hoechst 33258 staining is a commonly used method for visualizing apoptosis by observing chromatin condensation under a fluorescence microscope. Apoptotic cells were positively stained with fluorochrome Hoechst 33258 (Fig. 3). In colorectal cancer cells treated with 50 and $100 \mu \mathrm{mol} / \mathrm{L}$ myricetin for $48 \mathrm{~h}$, light microscopy showed that the apoptotic cells became rounder and smaller. In addition, there were vesicles in the cell membrane and apoptotic bodies in the cell. The percentage of apoptotic cells was 28.5 and $67.4 \%$ in the 50 and $100 \mu \mathrm{mol} / \mathrm{L}$ myricetin-treated groups, respectively. The number of apoptotic cells was positively correlated with the concentration of myricetin. Annexin V-FITC/PI double stain flow cytometry assay was used to determine the rate of cell apoptosis [19]. Flow cytometry revealed similar findings, with the apoptotic rate being positively correlated with the concentration of myricetin (Fig. 4ab). The results from the Western blotting assay further validated that myricetin reduced the ratio of $\mathrm{Bcl}-2 / \mathrm{Bax}$ and induced apoptosis in a dose-dependent manner. As the concentration of myricetin increased, the Bax content in the cells increased, and the Bcl- 2 content decreased (Fig. 4c-d). All of the above experiments showed that myricetin could induce the apoptosis of colon cancer cells.

\section{Myricetin induced autophagy by inhibiting PI3K/Akt/ mTOR signalling in HCT116 and SW620 cells}

Previous studies have shown that myricetin can induce apoptosis of HCT-15 and HT-29 human colon cancer cells $[11,12,20,21]$, and Cao J et al. in 2018 reported that myricetin can induce autophagy in HepG2 liver cancer cells [22]. However, the effect of myricetin on autophagy in colon cancer cells is still unknown. During the formation of autophagosomes, LC3-I transforms into LC3-II, resulting in a gradual increase in LC3-II expression [23]. Simultaneously, the expression of Beclin-1, 
Table 1 The growth inhibitory effect of myricetin against different human colon cancer cell lines expressed as a percentage

\begin{tabular}{|c|c|c|c|c|}
\hline \multirow[t]{2}{*}{ Conc.(umol/L) } & HCT116 & HT-29 & SW480 & SW620 \\
\hline & \multicolumn{4}{|l|}{ Inhibition(\% \pm SE) } \\
\hline 12.5 & $22.310 \pm 0.633$ & $2.057 \pm 0.532$ & $3.507 \pm 0.289$ & $3.440 \pm 0.662$ \\
\hline 25 & $37.323 \pm 0.752$ & $3.443 \pm 0.749$ & $6.160 \pm 0.346$ & $6.103 \pm 1.075$ \\
\hline 50 & $49.086 \pm 1.093$ & $19.733 \pm 0.687$ & $19.223 \pm 0.901$ & $19.933 \pm 2.149$ \\
\hline 100 & $56.146 \pm 1.002$ & $25.710 \pm 2.785$ & $26.957 \pm 3.165$ & $35.507 \pm 3.813$ \\
\hline 200 & $58.570 \pm 0.900$ & $37.253 \pm 2.428$ & $43.710 \pm 2.197$ & $49.070 \pm 0.563$ \\
\hline 400 & $64.030 \pm 1.109$ & $52.070 \pm 3.371$ & $55.197 \pm 3.599$ & $57.947 \pm 1.169$ \\
\hline Regression equation & $y=11.52 \ln (x)-1.134$ & $y=14.74 \ln (x)-39.37$ & $y=14.28 \ln (x)-36.20$ & $y=17.19 \ln (x)-44.53$ \\
\hline$R^{2}$ & 0.9215 & 0.9677 & 0.9762 & 0.9772 \\
\hline IC50( & 83.45 & 350.4 & 291.3 & 233.4 \\
\hline
\end{tabular}

which acts as a key induction gene in the autophagy process, also increases [24]. In the current study, Western blot analysis showed that the ratios of LC3-II/ $\beta$-actin and Beclin- $1 / \beta$-actin expression were increased in HCT116 and SW620 cells in a dose-dependent manner after myricetin treatment (Fig. 5a-b). In addition, electron microscopy revealed an increase in the number of autophagosomes in the cells treated with myricetin compared to those that were not treated (Fig. 5c). The percentage of autophagic cells was $73.1 \%$ in the myricetintreated group. Together, these findings verify that myricetin induces autophagy in human colon cancer cells.

Western blot analysis was used to detect the protein expression levels of phospho-PI3K, PI3K, phospho-Akt, Akt, phospho-mTOR, and mTOR in the HCT116 and SW620 cell lines. While phospho-PI3K, phospho-Akt, and phospho-mTOR were decreased in a dosedependent manner, there was no significant difference in the total PI3K, Akt, or mTOR. The ratios of p-Akt/Akt and $\mathrm{p}-\mathrm{mTOR} / \mathrm{mTOR}$ were significantly decreased following myricetin treatment (Fig. 5d). These data suggest that myricetin induces cell apoptosis and autophagy partly through inhibition of the PI3K/Akt/mTOR signalling pathway.

\section{Inhibition of autophagy enhanced myricetin-induced apoptosis in human colon cancer cells}

HCT116 and SW620 cells, with and without pretreatment with the autophagy inhibitor $3-\mathrm{MA}$ for $1 \mathrm{~h}$, were treated with $100 \mu \mathrm{mol} / \mathrm{L}$ myricetin for $48 \mathrm{~h}$. 3-MA was dissolved in RPMI-1640 medium (the final concentration was $5 \mathrm{mM}$ ). Cell viability was assessed via a resazurin cell viability assay (Fig. 6a), and the protein content was detected by Western blot analysis (Fig. 6b). Western blot analysis showed that the LC3-II/ $\beta$-actin ratio decreased in the cells that were pre-treated with 3MA compared to those that were not pre-treated, suggesting that autophagy was effectively inhibited by 3-MA treatment. In addition, cell viability was obviously reduced in HCT116 and SW620 cells that were pretreated with 3-MA for $1 \mathrm{~h}$ when compared with cells that were not pre-treated with 3-MA. Western blot

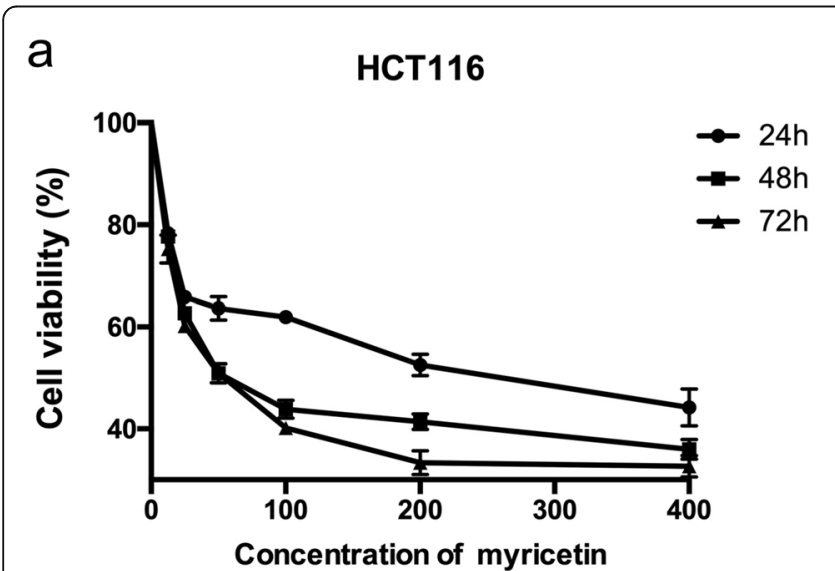

b

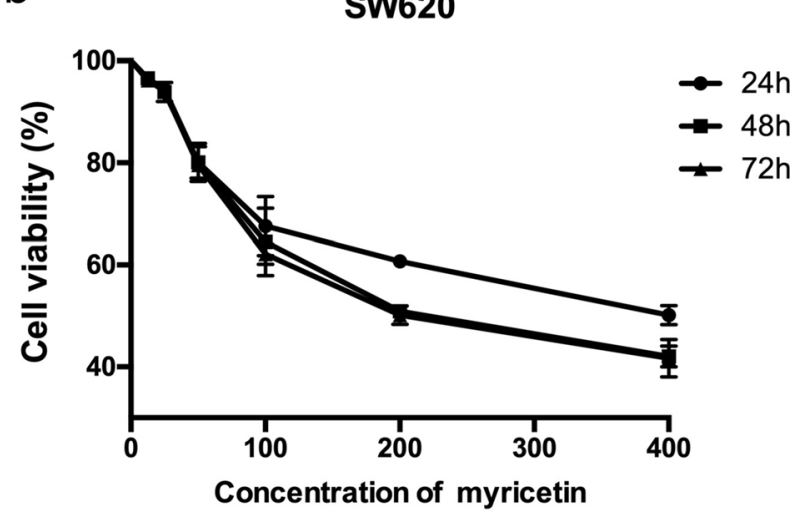

Fig. 2 Myricetin inhibited the viability of human colorectal cancer cells. HCT116 and SW620 cells were treated with 0-400 $\mu$ mol/L myricetin for $24 \mathrm{~h}, 48 \mathrm{~h}$, and $72 \mathrm{~h}$. Cell viability was analysed by means of a resazurin cell viability assay. Three replicate wells were set up in $96-$ well plates for each experimental group, and the experiment was repeated three times 

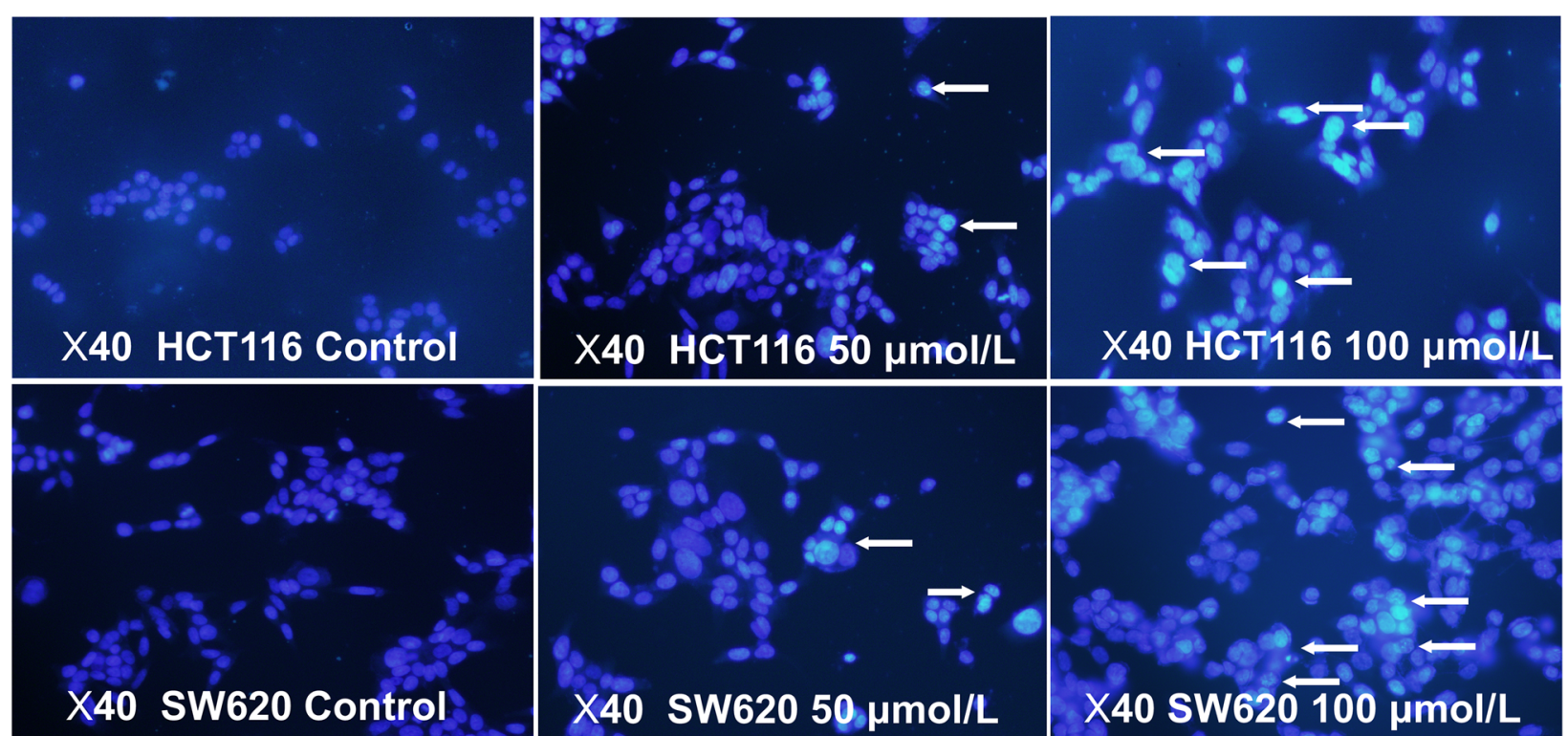

Fig. 3 Myricetin induced the apoptosis of HCT116 and SW620 cells. Hoechst 33258 staining was used to detect apoptosis, indicated by arrows ( $\times$ 200 magnification). Cells were treated with 50 or $100 \mu \mathrm{mol} / \mathrm{L}$ myricetin for $48 \mathrm{~h}$

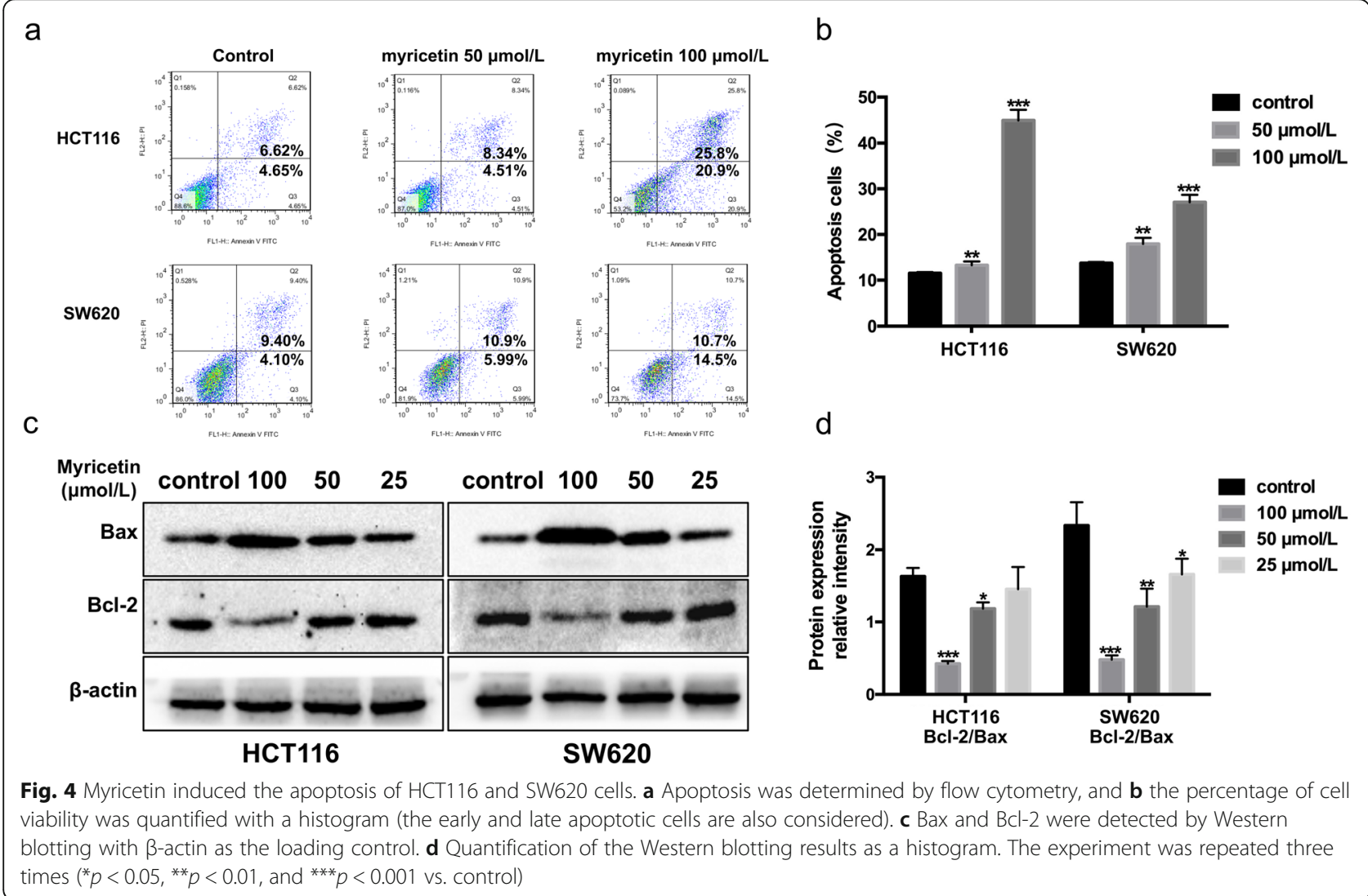


a

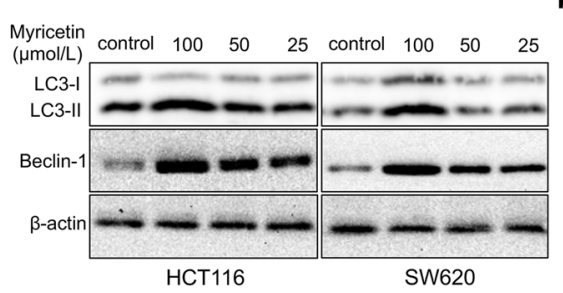

C

d

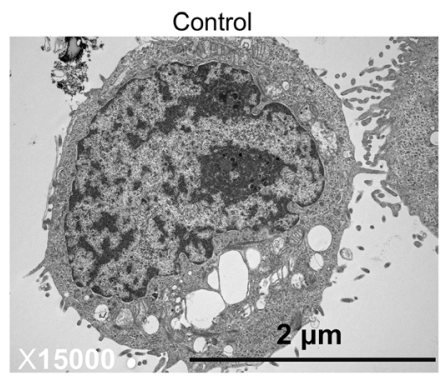

HCT116

SW620
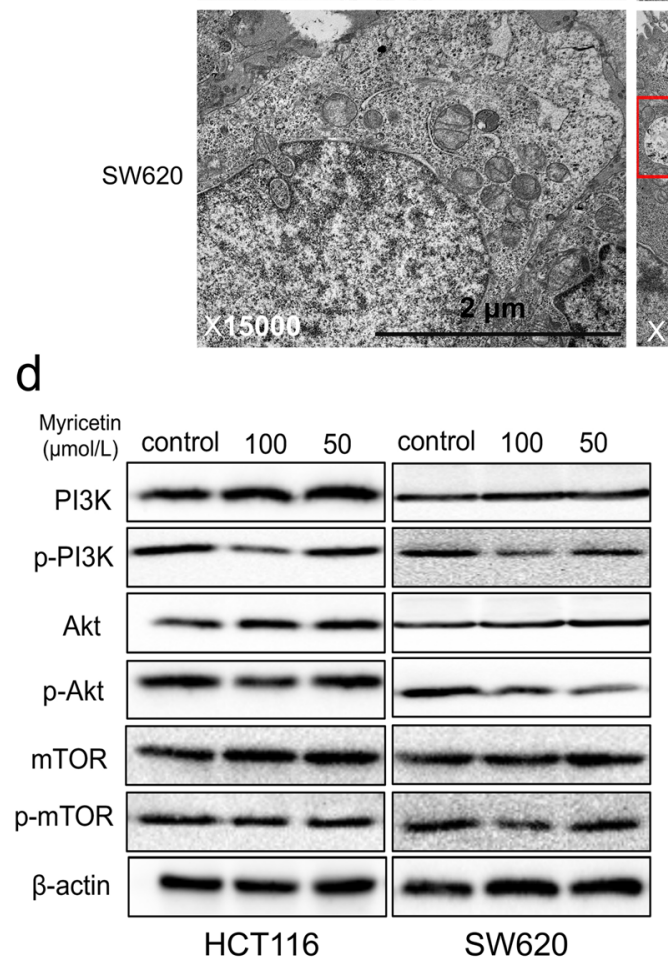

b
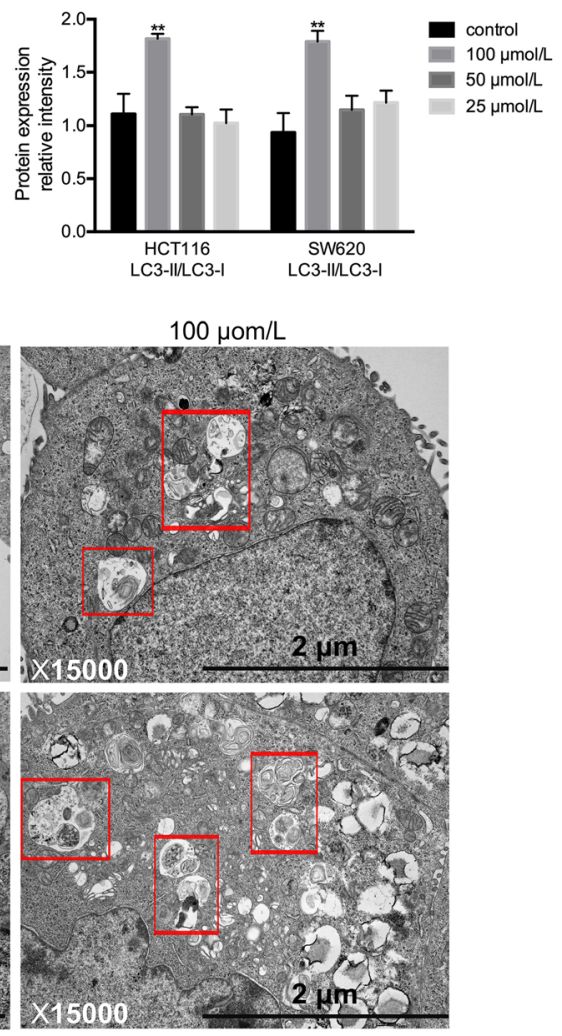
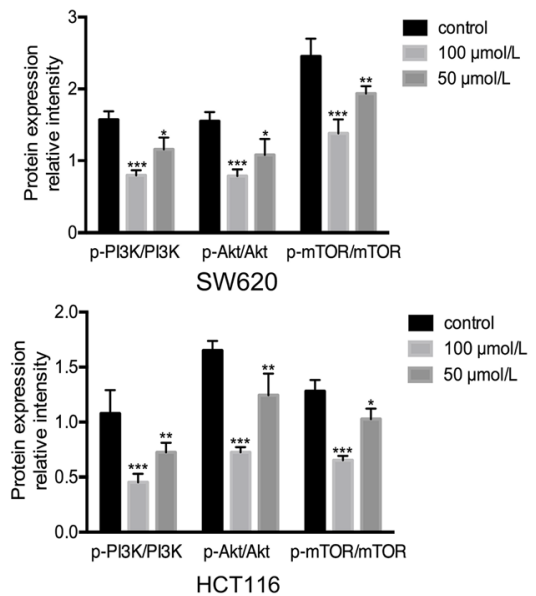

Fig. 5 Myricetin induced autophagy by inhibiting the activation of the PI3K/Akt/mTOR signalling pathway in HCT116 and SW620 cells. a LC3-I/II and Beclin-1 were detected by Western blotting with $\beta$-actin as the loading control. $\mathbf{b}$ Quantification of the Western blotting results with a histogram. c Transmission electron microscopy showed the number of autophagosomes (rectangle) in the cells treated with myricetin. $\mathbf{d}$ Protein levels were detected by Western blotting with $\beta$-actin as the loading control. Cells were treated with 50 or $100 \mu$ mol/L myricetin for $48 \mathrm{~h}$. The Western blots were analysed by densitometry in ImageJ, and the myricetin treatment group was compared with the control group. The experiment was repeated three times $\left({ }^{*} p<0.05,{ }^{* *} p<0.01\right.$, and ${ }^{* * *} p<0.001$ vs. control)

analysis also showed increased Bax content and decreased Bcl-2 content in the 3-MA pre-treated HCT116 and SW620 cells, suggesting that autophagic inhibition by 3-MA treatment enhanced myricetin-induced apoptosis in colorectal cancer cells (Fig. 6c-d).

\section{Discussion}

Chinese herbal medicine has been shown to improve immune function, promote phagocytosis of the reticuloendothelial system, protect the haematopoietic function of bone marrow and inhibit decreases in white blood cells 


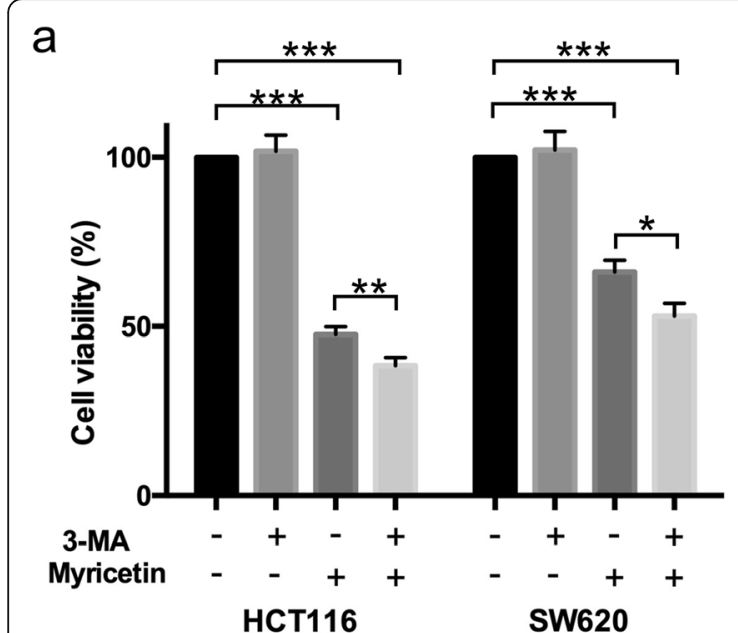

b
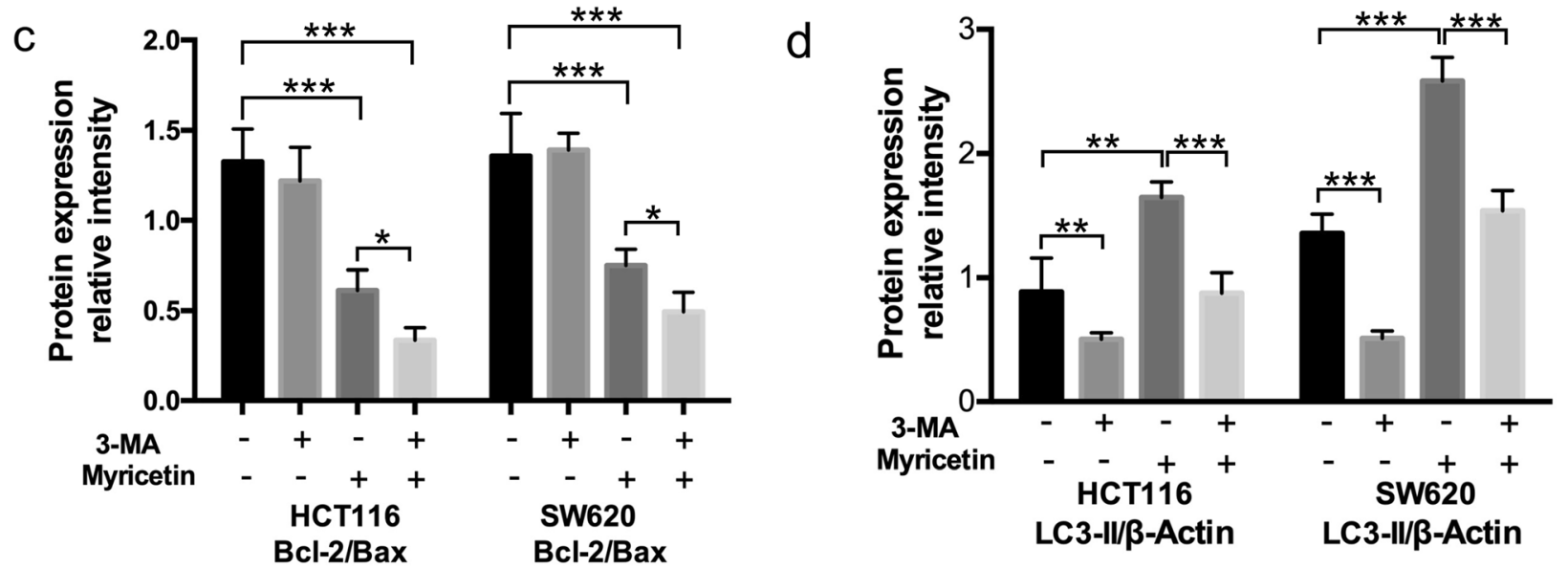

Fig. 6 Inhibition of autophagy enhanced apoptosis induced by myricetin in HCT116 and SW620 cells. a Cells, with or without pre-treatment with 3-MA for $1 \mathrm{~h}$, were treated with $100 \mathrm{\mu mol} / \mathrm{L}$ myricetin for $48 \mathrm{~h}$. Cell viability was investigated with a resazurin cell viability assay. b-d The Western blots show densitometry by ImageJ, and the myricetin treatment group was compared with the control group. Bax, BCl-2, and LC3-I/II were measured in cells following treatment with $100 \mu \mathrm{mol} / \mathrm{L}$ myricetin for $48 \mathrm{~h}$, with or without pre-treatment with 3-MA for $1 \mathrm{~h}$. The experiment was repeated three times $\left({ }^{*} p<0.05,{ }^{* *} p<0.01\right.$, and $\left.{ }^{* * *} p<0.001\right)$

and platelets $[25,26]$. In recent years, an increasing number of traditional Chinese herbal medicines have been used in the adjuvant treatment of cancer. Myricetin, a natural flavonoid, is widely distributed in many natural plants, such as the bark of Myrica nagi Thunb and the leaves of Ampelopsis sinica (Miq.) W.T. Wang and Camellia sinensis (L.) Kuntze [27, 28]. Most studies on the antitumour mechanism of myricetin have focused on its roles in inducing apoptosis and inhibiting inflammation, revealing its potential role in the progression of cell growth. In the present study, the effects of myricetin on the induction of colon cancer cell apoptosis and autophagy were investigated. Myricetin exhibited anticolon tumour activities that were mediated by apoptotic and autophagic pathways.

The PI3K/AKT/mTOR pathway is an intracellular signalling pathway that is important in regulating the cell cycle. Therefore, it is directly related to cellular quiescence, proliferation, cancer, and longevity [29, 30]. Phillips PA reported that myricetin induced pancreatic cancer cell death via the induction of apoptosis and inhibition of the PI3K signalling pathway [31]. The PI3K/ $\mathrm{AKT} / \mathrm{mTOR}$ signalling pathway might be involved in the regulation of autophagy and might affect cell proliferation [32-34]. In our study, Western blotting was used to detect the different signalling pathways in HCT116 and SW620 cells treated with myricetin, and the results demonstrated that myricetin-induced cell apoptosis and autophagy were mediated by the PI3K/AKT/mTOR signalling pathway.

Apoptosis and autophagy, two distinct modes of cell death, are both involved in the inhibitory effects of myricetin in colon cancer. In past reports, both autophagy and apoptosis have been found to occur in the same 
cells $[35,36]$. Autophagy and apoptosis are reported to intersect with each other via mTOR and AMPK signalling $[37,38]$. The AMPK and Bax signalling pathways have been demonstrated to activate autophagy [39], and numerous studies have revealed autophagy-induced apoptosis [40, 41]. Nevertheless, in recent years, some reports have shown that the inhibition of autophagy can increase the sensitivity of cancer cells to chemotherapeutic drugs by reducing drug resistance [42, 43]. It is generally believed that autophagy plays a dual role in the development of cancer. In the early stages of cancer, autophagy inhibits the growth of cancer cells. However, autophagy can also promote the development of tumours through a protective mechanism during later stages of cancer [44]. In our study, by inhibiting autophagy with 3-MA, we found that myricetin increased the apoptosis of human colorectal cancer cells. Hence, inhibition of autophagy promoted myricetin-induced apoptosis of colorectal cancer cells. The protective effect of autophagy is also an important mechanism by which colon cancer cells develop resistance to myricetin. Considering that myricetin itself inhibits colon cancer cell proliferation and induces apoptosis, the combination of myricetin and autophagy inhibitors may be a viable option for chemotherapy or adjuvant chemotherapy. In-depth studies of the mechanism of myricetin are still needed in the future.

\section{Conclusions}

Myricetin has been found to have anticancer properties in a variety of malignancies. However, the exact mechanisms of these effects are not fully known. There are few studies on the efficacy of myricetin as an anticancer agent in colon cancer, and little is known about the regulatory effects of myricetin on autophagy. The findings from the present study suggest that myricetin induces colon cancer cell autophagy and apoptosis by inhibiting PI3K/Akt/mTOR signalling. In addition, the inhibition of autophagy increases the apoptosis of myricetin-treated colon cancer cells. Therefore, myricetin may become a viable candidate for chemotherapy; it could be used alone to exert tumour inhibitory effects or as adjuvant chemotherapy to inhibit autophagy. These studies may provide further evidence for the potential use of myricetin in the treatment of colon cancer. The findings lay the basis for developing more efficient anticolon cancer drugs derived from natural products. Future research is needed to develop highly effective antitumour drugs that target cancer cells.

\section{Abbreviations}

MA: 3-methyladenine; LC3: Microtubule-associated protein 1 light chain 3; PI3K: Phosphatidyl inositide 3-kinase; mTOR: Mammalian target of rapamycin; ATCC: American Type Culture Collection; DMSO: Dimethyl sulfoxide; PBS: Phosphate-buffered saline; RIPA: Radio immunoprecipitation assay;
SDS: Sodium dodecyl sulfate; PVDF: Polyvinylidene fluoride; FITC: Fluorescein isothiocyanate; PI: Propidium iodide

Acknowledgements

Not applicable.

\section{Authors' contributions}

LW and SWY designed the research. MLZ and PMZ conducted the experiments. MLZ and MJ analysed the data. MLZ wrote the manuscript. All authors read and approved the final manuscript.

\section{Funding}

This work was supported by the National Natural Science Foundation of China (81803570), the Postdoctoral Science Foundation of China (2019 M652411), the Postdoctoral Innovation Project of Shandong Province (201902044) and the Jinan Science and Technology Bureau (201907111).

\section{Availability of data and materials}

The datasets used and/or analysed during the current study are available from the corresponding author on reasonable request.

Ethics approval and consent to participate

Not applicable.

Consent for publication

Not applicable.

\section{Competing interests}

The authors declare that they have no competing interests.

\section{Author details}

${ }^{1}$ School of Pharmaceutical Sciences, Cheeloo College of Medicine, Shandong University, Jinan 250012, China. ${ }^{2}$ Department of Pharmacy, Jinan Central Hospital, Cheeloo College of Medicine, Shandong University, Jinan 250013, China.

Received: 21 November 2019 Accepted: 19 May 2020

Published online: 06 July 2020

\section{References}

1. Siegel RL, Miller KD, Jemal A. Cancer statistics, 2018. CA Cancer J Clin. 2018; 67(1):7-30.

2. Kuipers EJ, Grady WM, Lieberman D, Seufferlein T, Sung JJ, Boelens PG, Velde CJH, Watanabe T. Colorectal cancer. Nat Rev Dis Primers. 2015;1: 15065.

3. Miller KD, Siegel RL, Lin CC, Mariotto AB, Kramer JL, Rowland JH, Stein KD, Alteri R, Jemal A. Cancer treatment and survivorship statistics, 2016. CA Cancer J Clin. 2016:66(4):271-89.

4. Canada AT, Giannella E, Nguyen TD, Mason RP. The production of reactive oxygen species by dietary flavonols. Free Radic Biol Med. 1990;9(5):441-9.

5. Miean KH, Mohamed S. Flavonoid (Myricetin, Quercetin, Kaempferol, Luteolin, and Apigenin) content of edible tropical plants. Food Chem. 2001; 49(6):3106-12

6. Ye C, Zhang C, Huang $H$, Yang B, Xiao G, Kong D, Tian Q, Song Q, Song Y, Tan $\mathrm{H}$, et al. The natural compound Myricetin effectively represses the malignant progression of prostate cancer by inhibiting PIM1 and disrupting the PIM1/CXCR4 interaction. Cell Physiol Biochem. 2018;43(3):1230-44.

7. Rodgers EH, Grant MH. The effect of the flavonoids, quercetin, myricetin and epicatechin on the growth and enzyme activities of MCF7 human breast cancer cells. Chem Biol Interact. 1998;116(3):213-28.

8. Feng J, Chen X, Wang Y, Du Y, Sun Q, Zang W, Zhao G. Myricetin inhibits proliferation and induces apoptosis and cell cycle arrest in gastric cancer cells. Mol Cell Biochem. 2015:408(1-2):163-70.

9. Zhang S, Wang L, Liu H, Zhao G, Ming L. Enhancement of recombinant myricetin on the radiosensitivity of lung cancer A549 and H1299 cells. Diagn Pathol. 2014;9:68.

10. Nirmala P, Ramanathan M. Effect of myricetin on 1,2 dimethylhydrazine induced rat colon carcinogenesis. J Exp Ther Oncol. 2011:9(2):101-8.

11. Kim ME, Ha TK, Yoon JH, Lee JS. Myricetin induces cell death of human colon cancer cells via BAX/BCL2-dependent pathway. Anticancer Res. 2014; 34(2):701-6. 
12. Lee JH, Choi YJ, Park SH, Nam MJ. Potential role of nucleoside diphosphate kinase in myricetin-induced selective apoptosis in colon cancer HCT-15 cells. Food Chem Toxicol. 2018;116(Pt B):315-22.

13. Bursch W, Ellinger A, Gerner C, Fröhwein U, Schulte-Hermann R. Programmed cell death (PCD). Apoptosis, autophagic PCD, or others? Ann N Y Acad Sci. 2000;926:1-12.

14. Kaur P, Robin, Mehta RG, Singh B, Arora S. Development of aqueous-based multiherbal combination using principal component analysis and its functional significance in HepG2 cells. BMC Complement Altern Med. 2019; 19:18.

15. Yu F-F, Lin X-L, Wang X, Ping Z-G, Guo X. Comparison of apoptosis and autophagy in human chondrocytes induced by the T-2 and HT-2 toxins. Toxins (Basel). 2019;11(5):E260.

16. Hung AC, Tsai C-H, Hou M-F, Chang W-L, Wang C-H, Lee Y-C, Ko A, Hu SC-S, Chang F-R, Hsieh P-W, et al. The synthetic $\beta$-nitrostyrene derivative CYTRx20 induces breast cancer cell death and autophagy via ROS-mediated MEK/ERK pathway. Cancer Lett. 2016;371(2):251-61.

17. Lee EB, Cheon MG, Cui J, Lee YJ, Seo EK, Jang HH. The quinone-based derivative, HMNQ induces apoptotic and autophagic cell death by modulating reactive oxygen species in cancer cells. Oncotarget. 2017;8(59): 99637-48.

18. Wang L, Li Z, Wang C, Yang Y, Sun L, Yao W, Cai X, Wu G, Zhou F, Zha X. Ecadherin decreased human breast cancer cells sensitivity to staurosporine byup-regulating Bcl-2 expression. Arch Biochem Biophys. 2009;481(1):11622.

19. Wang W, Chen J, Zhang B, Lu S, Wang F, Peng L, Dai J, Sun Y. Curcumin inhibits proliferation and enhances apoptosis in A549 cells by downregulating IncRNA UCA1. Pharmazie. 2018;73(7):402-7.

20. Kuntz $\mathrm{S}$, Wenzel $U$, Daniel $\mathrm{H}$. Comparative analysis of the effects of flavonoids on proliferation, cytotoxicity, and apoptosis in human colon cancer cell lines. Eur J Nutr. 1999;38(3):133-42.

21. Shiomi K, Kuriyama I, Yoshida H, Mizushina Y. Inhibitory effects of myricetin on mammalian DNA polymerase, topoisomerase and human cancer cell proliferation. Food Chem. 2013;139(1-4):910-8.

22. Cao J, Chen H, Lu W, Wu Y, Wu X, Xia D, Zhu J. Myricetin induces protective autophagy by inhibiting the phosphorylation of mTOR in HepG2 cells. Anat Rec (Hoboken). 2018;301(5):786-95.

23. Taguchi-Atarashi N, Hamasaki M, Matsunaga K, Omori H, Ktistakis NT, Yoshimori T, Noda T. Modulation of local Ptdlns3P levels by the PI phosphatase MTMR3 regulates constitutive autophagy. Traffic. 2010;11(4): 468-78

24. Wang B, Zhou T-Y, Nie C-H, Wan D-L, Zheng S-S. Bigelovin, a sesquiterpene lactone, suppresses tumor growth through inducing apoptosis and autophagy via the inhibition of mTOR pathway regulated by ROS generation in liver cancer. Biochem Biophys Res Commun. 2018;499:156-63.

25. Lin H, Liu J, Zhang Y. Developments in cancer prevention and treatment using traditional Chinese medicine. Front Med. 2011;5(2):127-33.

26. Li SG, Chen HY, Ou-Yang CS, Wang X-X, Yang Z-J, Tong Y, Cho WCS. The efficacy of Chinese herbal medicine as an adjunctive therapy for advanced non-small cell lung cancer: a systematic review and meta-analysis. PLoS One. 2013;8(2):e57604.

27. Devi KP, Rajavel T, Habtemariam S, Nabavi SF, Nabavi SM. Molecular mechanisms underlying anticancer effects of myricetin. Life Sci. 2015;142: 19-25.

28. Jeganathan B, Punyasiri PA, Kottawa-Arachchi JD, Ranatunga MA, Abeysinghe IS, Gunasekare MT, Bandara BM. Genetic variation of flavonols Quercetin, Myricetin, and Kaempferol in the Sri Lankan Tea (Camellia sinensis L.) and their health-promoting aspects. Int. J Food Sci. 2016;2016: 6057434.

29. Johnson SM, Gulhati P, Rampy BA, Han Y, Rychahou PG, Doan HQ, Weiss HL, Evers BM. Novel expression patterns of PI3K/Akt/mTOR signaling pathway components in colorectal cancer. J Am Coll Surg. 2010;210(5):767-76.

30. Xia P, Xu X. PI3K/Akt/mTOR signaling pathway in cancer stem cells: from basic research to clinical application. Am J Cancer Res. 2015:5(5):1602-9.

31. Phillips PA, Sangwan V, Borja-Cacho D, Dudeja V, Vickers SM, Saluja AK. Myricetin induces pancreatic cancer cell death via the induction of apoptosis and inhibition of the phosphatidylinositol 3-kinase (PI3K) signaling pathway. Cancer Lett. 2011;308(2):181-8.

32. Manfredi Gl, Dicitore A, Gaudenzi G, Caraglia M, Persani L, Vitale G. PI3K/Akt/ mTOR signaling in medullary thyroid cancer: a promising molecular target for cancer therapy. Endocrine. 2015;48(2):363-70.
33. Zhao Z, Yu Z, Li J, Ouyang X. Gefitinib induces lung cancer cell autophagy and apoptosis via blockade of the PI3K/AKT/mTOR pathway. Oncol Lett. 2016;12(1):63-8

34. Chen L, Song T, Xiao J, Huang Z, Li Y, Lin T. Tripchlorolide induces autophagy in lung cancer cells by inhibiting the PI3K/AKT/mTOR pathway and improves cisplatin sensitivity in A549/DDP cells. Oncotarget. 2017;8(38): 63911-22.

35. Swart C, Du Toit A, Loos B. Autophagy and the invisible line between life and death. Eur J Cell Biol. 2016;95(12):598-610.

36. Baehrecke EH. Autophagy: dual roles in life and death? Nat Rev Mol Cell Biol. 2005:6(6):505-10.

37. Jing K, Song KS, Shin S, Kim N, Jeong S, Oh HR, Park JH, Seo KS, Heo JY, Han I, et al. Docosahexaenoic acid induces autophagy through p53/AMPK mTOR signaling and promotes apoptosis in human cancer cells harboring wild-typep53. Autophagy. 2011;7(11):1348-58.

38. Kumar D, Shankar S, Srivastava RK. Rottlerin induces autophagy and apoptosis in prostate cancer stem cells via PI3K/Akt/mTOR signaling pathway. Cancer Lett. 2014;343(2):179-89.

39. Kandala PK, Srivastava SK. Regulation of macroautophagy in ovarian cancer cells in vitro and in vivo by controlling glucose regulatory protein 78 and AMPK. Oncotarget. 2012;3(4):435-49.

40. Qi W, Li Z, Yang C, Jiangshan Dai J, Zhang Q, Wang D, Wu C, Xia L, Xu S. Inhibitory mechanism of muscone in liver cancer involves the induction of apoptosis and autophagy. Oncol Rep. 2020;43(3):839-50.

41. Yao X, Sha S, Wang Y, Sun X, Cao J, Kang J, Jiang L, Chen M, Ma Y. Perfluorooctane sulfonate induces autophagy-dependent apoptosis through spinster 1-mediated lysosomal-mitochondrial axis and impaired mitophagy. Toxicol Sci. 2016;153(1):198-211.

42. Sun W, Zu Y, Fu X, Deng Y. Knockdown of IncRNA-XIST enhances the chemosensitivity of NSCLC cells via suppression of autophagy. Oncol Rep. 2017;38:3347-54.

43. Zhang $\mathrm{K}$, Chen J, Zhou H, Chen Y, Zhi Y, Zhang B, Chen L, Chu X, Wang R, Zhang C. PU.1/microRNA-142-3p targets ATG5/ATG16L1 to inactivate autophagy and sensitize hepatocellular carcinoma cells to sorafenib. Cell Death Dis. 2018:9(3):312.

44. Maes H, Rubio N, Garg AD, Agostinis P. Autophagy: shaping the tumor microenvironment and therapeutic response. Trends Mol Med. 2013;19(7): 428-46.

\section{Publisher's Note}

Springer Nature remains neutral with regard to jurisdictional claims in published maps and institutional affiliations.
Ready to submit your research? Choose BMC and benefit from:

- fast, convenient online submission

- thorough peer review by experienced researchers in your field

- rapid publication on acceptance

- support for research data, including large and complex data types

- gold Open Access which fosters wider collaboration and increased citations

- maximum visibility for your research: over $100 \mathrm{M}$ website views per year

At $\mathrm{BMC}$, research is always in progress.

Learn more biomedcentral.com/submissions 